\title{
Líðan leikskólakennara og leiðbeinenda í leikskólum í kjölfar efnahagshrunsins
}

\author{
Guðbjörg Linda Rafnsdóttir og Hjördís Sigursteinsdóttir
}

\footnotetext{
$\checkmark$ Abstract $\quad \longrightarrow$ Um höfundana About the authors $>$ Heimildir
}

Líðan leikskólakennara og leiðbeinenda, svo og aðbúnaður á vinnustað, er meðal pess sem getur haft áhrif á leikskólabörn og proskaferil peirra. Dví er brýnt að rannsaka líðan pessara starfshópa og hvaða pættir í vinnuumhverfinu styðja við eða draga úr góđri líðan starfsfólksins. Pað er viðfangsefni pessarar greinar. Vinnufyrirkomulag um pað bil helmings allra leikskólakennara og leiðbeinenda, sem starfa hjá sveitarfélögum hér á landi, er rannsakað, svo og tengsl pess við sjálfmetna andlega líðan peirra. Meginrannsóknarspurningin er hvort tengsl séu á milli pess hvernig leikskólakennarar og leiðbeinendur upplifa vinnufyrirkomulagspætti eins og stjórnun, stuðning, vinnuálag, skilgreiningu hlutverka og próun í starfi annars vegar og andlegrar líðanar peirra hins vegar. Greinin byggir á langtíma panelgögnum par sem sömu 480 leikskólakennurum og leiðbeinendum var fylgt eftir árin 2010, 2011, 2013 og 2015. Notað var svokallað GEE-líkan (e. generalized estimating equation) til að spá fyrir um andlega líðan starfsfólksins á pessum árum. Niðurstöðurnar gerðu almennt ekki greinarmun á leikskólakennurum og leiðbeinendum. Endurteknar mælingar sýndu að sjálfmetin andleg líðan leikskólakennaranna og leiðbeinendanna versnaði á milli fyrirlagna. Detta kom einnig fram pegar tillit hafði verið tekið til kyns, aldurs og hjúskaparstöðu. Allir pættir í vinnuumhverfinu, sem til skoðunar voru, versnuðu á milli fyrirlagna að mati starfffólksins. Sá páttur, sem versnaði mest, var vinnuálag. Athyglisvert er pó að tengslin voru veik á milli vinnuálags og andlegrar líðanar. Góð stjórnun og félagslegur stuðningur hafði jákvæð áhrif á líðanina. Mikilvægt er að peir sem standa að stefnumótun á sviði leikskólanna taki pessar niðurstöður til skoðunar og að greint verði enn frekar hvað veldur pví að áðurnefndir vinnufyrirkomulagspættir og líðan starfsfólksins versna að peirra mati á milli fyrirlagna. Með pví móti er ekki einungis stuðlað að bættu vinnuumhverfi leikskólakennara og leiðbeinenda heldur einnig leikskólabarnanna og að leikskólabörnunum sé sinnt á pann hátt sem nauðsynlegt er fyrir líðan peirra og proska.

Efnisorð: Andleg líðan, félagslegur stuðningur, starfsfólk leikskóla, stjórnun, vinnuálag, vinnufyrirkomulag, vinnuumhverfi

\section{Inngangur}

Starfsfólk leikskóla getur haft mikil áhrif á líðan og proskaferil leikskólabarna. Detta sýna meðal annars erlendar rannsóknir (Burchinal o.fl., 2008; Hamre og Pianta, 2001; Hestenes, Kontos og Bryan, 1993; Mashburn o.fl., 2008). Í rannsókn Hamre og Pianta (2001) kemur fram að leikskólabörn sem njóta góðrar umhyggju, sem felur í sér að einhver annast pau af áhuga, hlýju 
og ábyrgð, eru líklegri til að próa með sér góðan vitsmunaproska en börn sem njóta ekki slíkrar umönnunar. Rannsóknir Buettner, Jeon, Hur og Garcia (2016) og Jennings og Greenberg (2009) sýna jafnframt að félags- og tilfinningaleg geta (e. social-emotional capacity) kennara og peirra eigin velferð styður við góða félags- og tilfinningalega námshætti (e. social and emotional learning practices) svo sem næmni, svörun og tilfinningalegan stuðning í leikskólunum. Í rannsókn Buettner og félaga (2016) kemur fram að andlegt álag, vinnutengd streita, tilfinningaleg örmögnun og punglyndi meðal leikskólakennara geta komið í veg fyrir að peir nái að takast á við tilfinningar og hegðun barnanna sem peir sinna. Einnig geta pessir starfstengdu pættir hamlað faglegri próun kennara og komið í veg fyrir helgun í starfi, starfsánægju og hollustu við vinnustaðinn. Leikskólakennari sem upplifir tilfinningalega örmögnun og kulnun í starfi er síður líklegur til að sýna börnunum í leikskólanum jákvæðni og umhyggju en sá sem líður vel í starfinu (Jennings, 2015; Koles, O'Connor og Collins, 2013; Rentzou, 2012; Whitaker, DearthWesley og Gooze, 2015). Í ljósi pessa er skiljanlegt að undanfarin ár hefur verið vaxandi áhugi á sálfélagslegri líðan leikskólakennara og tengsla hennar við faglegt starf peirra (Hall-Kenyon, Bullough, MacKay og Marshall, 2014).

Í pessari grein er fjallað um sjálfmetna andlega líðan leikskólakennara og leiðbeinenda hér á landi og tengsl hennar við pæetti í vinnuumhverfinu, svo sem stjórnun, stuðning, vinnuálag, skilgreiningu hlutverka og próun í starfi. Einnig er horft til bakgrunnspáttanna aldurs, kyns, hjúskaparstöðu, menntunar og starfsreynslu. Við fylgjum einstaklingum eftir og berum saman líðan peirra á tímabilinu 2010-2015, pað er tveimur til sjö árum eftir eitt mesta efnahagshrun pjóðarinnar. Rannsóknin fjallar ekki um líðan leikskólabarna en vísað er til áðurnefndra rannsókna pegar dregin er sú ályktun að líðan starfsfólks leikskólanna geti haft smitáhrif á börnin. Dví er mikilvægt að vinnufyrirkomulag leikskólakennara og leiðbeinenda sé eins og best verður á kosið og styðji við vellíðan peirra. Með pví móti er ekki einungis stuðlað að bættri starfsánægju, heldur einnig að pví að börnunum sé sinnt á pann hátt sem nauðsynlegt er fyrir líðan peirra og proska.

\section{Staðan á Íslandi}

Störf í leikskólum hafa frá upphafi verið hefðbundin kvennastörf og samkvæmt Dórdísi Dórðardóttur (2005) hefur leikskólastarfið aldrei haft sterka stöðu á vinnumarkaðinum eða notið nægilegrar virðingar í samfélaginu. Sterkasta birtingarmynd pess er hversu lág laun eru greidd fyrir fagleg uppeldis- og umönnunarstörf í samanburði við hefðbundin karlastörf. Dórdís bendir einnig á að eftir pví sem ofar dregur í skólakerfinu pá lækkar hlutfall kvenna meðal kennara sem аð hennar mati endurspeglar viðteknar hugmyndir um virðingarsess skólastiganna og valdatengsl kynjanna.

Í Aðalnámskrá leikskóla frá árinu 2011 kemur fram að tryggja eigi samræmi og samhengi í menntun allt frá leikskóla til háskóla og fullorðinsfræðslu. Dar segir að hlutverk leikskólakennara sé að:

[...] vera leiðandi í mótun uppeldis- og menntastarfsins, fylgjast með nýjungum og miðla pekkingu. Hann á að vera góð fyrirmynd í starfi með börnum og leitast við að styrkja faglegt hlutverk leikskólans. Litið er á leikskólakennara sem leiðandi samverkamann barna, foreldra og annars starfsfólks leikskóla. Honum ber að sjá til pess að hvert barn sé virt að verðleikum og að námsumhverfið sé skipulagt á pann veg að börn fái notið bernsku sinnar.

(Mennta- og menningarmálaráđuneytið, 2013, bls. 23).

Dví er ljóst að fyrir leikskólakennara skiptir fagleg pekking peirra og vinnuumhverfi miklu. Síðastliðinn áratug hafa orðið töluverðar breytingar á faglegum kröfum sem gerðar eru til leikskólakennara með lengingu leikskólakennaranámsins. Pó hefur próunin síðustu ár verið sú að hlutfall leikskólakennara af peim sem sinna uppeldi og menntun leikskólabarna hefur lækkað. 
Árið 2008 var hlutfall leikskólakennara 32\% og hækkaði markvisst í 35\% árið 2013 en síðan pá hefur hlutfallið lækkað ár frá ári og var komið í 28\% árið 2017. Hlutfall ófaglærðra hefur verið í kringum 45\% frá árinu 2013 en var 47\% árið 2017 og 18\% eru með aðra uppeldismenntun, s.s. grunnskólakennaranám, námí proskapjálfun, diplómanámíleikskólafræðum eða leikskólaliðanám (Hagstofa Íslands, 2018).

Einnig hafa orðið breytingar á vinnuumhverfi leikskólakennara sem rekja má til sparnaðaraðgerða sveitarfélaga í kjölfar efnahagshrunsins á haustmánuðum 2008. Detta lýsir sér meðal annars í sameiningum leikskóla en leikskólum hefur fækkað um 30 frá árinu 2009. Árið 2016 voru 254 leikskólar starfandi en peir voru flestir árið 2009 eða 284 talsins. Við pað bætist að frá árinu 2009 hefur hlutfall barna sem sækir leikskóla hækkað, farið úr 82\% í rúm 86\% árið 2016 en stöðugildum í leikskólum fækkað (Hagstofa Íslands, 2017). Milli áranna 2009 og 2010 fækkaði stöðugildum í leikskólum úr 4.847 í 4.770, frá árinu 2010 til ársins 2014 fjölgaði peim í 5.289 en fækkaði síðan í 5.191 árið 2016 (Hagstofa Íslands, 2018).

Rannsókn Hjördísar Sigursteinsdóttur, Guðbjargar Lindu Rafnsdóttur og Porgerðar Einarsdóttur (2011) sýnir að kennarar í grunnskólum, tónlistarskólum og leikskólum fundu fyrir minnkandi starfsöryggi í kjölfar efnahagshrunsins og um fjórðungur peirra taldi að andleg heilsa sín væri verri eftir hrunið en hún hefði verið fyrir hrun. Deir kennarar, sem álitu sig búa við skert starfsöryggi og versnandi heilsufar, voru líklegri en aðrir til að vilja skipta um starfsvettvang. Jafnframt kemur í ljós í rannsókn peirra að af pessum premur kennarastéttum virtust veikindafjarvistir hafa verið mestar meðal leikskólakennara. Í rannsókn Guðbjargar Lindu Rafnsdóttur og Hjördísar Sigursteinsdóttur (2016) kemur jafnframt í ljós að árið 2010 höfðu 26,3\% leikskólakennara, sem unnu í leikskólum par sem uppsagnir höfðu átt sér stað, leitað til læknis vegna veikinda eða heilsubrests sem rekja mátti að peirra mati til aðstæðna í vinnunni síðustu 12 mánuði. Hlutfallið jókst í 32\% árið 2011 en lækkaði svo aftur niður í 25\% árið 2013. Laufey Axelsdóttir og Gyða Margrét Pétursdóttir (2014) benda á að efnahagslegur samdráttur hjá sveitarfélögum í kjölfar hruns hafi haft neikvæð áhrif á leikskólakennarastarfið og stöđu kvenna sem pví sinna. Samdrátturinn hafi pannig - að peirra mati - ýtt undir pað að undirskipun kvenna á vinnumarkaðinum sé viðhaldið auk pess sem efnahagslegur samdráttur skapi aðstæður sem hugsanlega hafi neikvæð áhrif á líðan og öryggi leikskólabarna. Á hinn bóginn sýnir rannsókn Geirs Gunnlaugssonar (Gunnlaugsson, 2016) lítil eða engin áhrif kreppunnar á heilsu barna hér á landi.

\section{Andleg líðan, faglegur bakgrunnur og vinnuumhverfið}

Dekkt er að ýmsir pættir í vinnuumhverfinu geta haft áhrif á líðan starfsfólks og eru sumir peirra skoðaðir í pessari grein. Rannsóknir sýna til að mynda tengsl á milli pess hvernig fólki líður og möguleikanum á starfspróun og starfsframa (Karanika-Murray og Weyman, 2013; Liu, Yang og Yu, 2014; Mellor og Webster, 2013), starfskrafna, streitu, vinnufyrirkomulags og stjórnunar, sjálfræðis í starfi og samskipta milli samstarfsfólks og við yfirmenn (Guðbjörg Linda Rafnsdóttir, 2001; Guðmundur Ingi Guðmundsson og Guðbjörg Linda Rafnsdóttir, 2010; Riggio, 2009; Schulte og Vainio, 2010; Sigursteinsdóttir og Rafnsdóttir, 2015). Einnig sýna rannsóknir tengsl líðanar við að óttast að ná ekki tilsettum markmiðum, svo og við einelti og félagslega útilokun (Guðbjörg Linda Rafnsdóttir og Kristinn Tómasson, 2004; Hjördís Sigursteinsdóttir, 2017; Kelloway, 2017).

Starfspróun er mjög mikilvæg fyrir kennara svo peir geti viðhaldið sérfræðipekkingu sinni og gæðum kennslu (Bloom, 1988; Fantuzzo o.fl., 2012; Manlove, 1993; Mennta- og menningarmálaráðuneytið, 2013). Fantuzzo og félagar (2012) telja að kennarar, sem fá fagleg starfspróunartækifæri, séu líklegri en aðrir til að læra nýja færni sem endurspeglast í vinnubrögðum peirra, jákvæðum samskiptum við börnin og samstarfi við aðra kennara. Dar af leiðandi má ætla að pessir kennarar hafi meira sjálfstraust til að vinna með börnunum, sem getur síðan haft jákvæð áhrif á sálfélagslega líðan kennaranna. Pótt rannsókn Manlove (1993) gefi til kynna að 
fyrirkomulag vinnu og pátttaka kennara í starfspróun tengist starfsánægju pá hafa fáar rannsóknir skoðað hvort tækifæri til starfspróunar séu tengd andlegri vellíðan starfsfólks leikskóla, eins og gert er í pessari grein.

Annar mikilvægur páttur í umönnun barna er uppbygging og skipulag leikskólastarfsins. Degar kennarar starfa í öruggu og skipulögðu vinnuumhverfi eru peir mun færari um að veita börnunum stuðning en annars væri (Friedman-Krauss, Raver, Morris og Jones, 2014; Mashburn o.fl., 2008). Óskipulagt vinnuumhverfi hefur hins vegar tengsl við neikvæð samskipti á milli leikskólakennara og leikskólabarna (Buettner o.fl., 2016). Rimm-Kaufman og Hamre (2010) benda auk pess á að menntun og starfsreynsla tengist gæðum samskipta milli leikskólakennara og leikskólabarna. Dannig hafi aukin menntun og starfsreynsla kennara í för með sér að peir verði hæfari til að takast á við krefjandi hegðun leikskólabarna, sem er - samkvæmt Friedman-Krauss og félögum (2014) - ein algengasta orsök streitu meðal leikskólakennara. Hugsanlegt er að leikskólakennarar með meiri starfsreynslu hafi komið sér upp bjargráđum til að draga úr andlegu álagi og pað hjálpi peim að takast á við neikvæðar tilfinningar í tengslum við leikskólakennarastarfið. Vísbendingar eru um að nýir leikskólakennarar séu líklegri en peir sem hafa lengri starfsaldur til að upplifa kulnun í starfi og hætta störfum innan fimm ára frá ráðningu peirra. Pá kemur einnig fram í rannsókn Wells (2015) að neikvæð samskipti við yfirmann auki starfsmannaveltu.

Mikið vinnuálag og óskýr hlutverk (Doi, 2005; Giorgi o.fl., 2017; Hjördís Sigursteinsdóttir, Guðbjörg Linda Rafnsdóttir og Guðbjörg Andrea Jónsdóttir, 2017; Liu o.fl., 2014), svo og fá bjargráð og lítill félagslegur stuðningur (Demerouti, Bakker, Nachreiner og Schaufeli, 2001; Martin, Karanika-Murray, Biron og Sanderson, 2016; Stansfeld og Candy, 2006), geta leitt til líkamlegra og andlegra heilsufarsvandamála hjá starfsfólki. Í rannsókn Valgerðar Magnúsdóttur og Önnu Bóru Baldursdóttur (2008) á starfsumhverfi grunnskólakennara og líðan peirra í starfi kemur fram að kennarar, sem verða sjaldan fyrir hlutverkaárekstrum í starfi og telja jafnframt starfið vel skilgreint, eru mun ánægðari í starfi sínu en aðrir. Pær álykta að mikilvægt sé að vinnufyrirkomulag valdi sem minnstri hættu á hlutverkaárekstrum, skýr hlutverk kennara auki faglegt sjálfstraust peirra og líkur á kulnun í starfi minnki. Ef hlutverk kennara er óskýrt pannig að ekki er ljóst til hvers er ætlast af honum er hætt við að tilfinningar hans í garð nemenda og samstarfsfólks verði neikvæðar (Anna Póra Baldursdóttir, 2002). Detta tengist kenningum Bloom (1988) sem telur að pað séu einkum fimm pættir á vinnustaðnum sem séu mikilvægir fyrir starfsánægju og hollustu leikskólakennara. Dessir fimm pættir eru (1) sambandið milli vinnufélaga og yfirmanna, (2) starfið sjálft, (3) laun, (4) möguleikar á starfspróun og (5) heildarvinnuskilyrði. Nýrri rannsóknir sýna jafnframt að pegar leikskólakennarar upplifa pessa fimm pætti sem hagstæða pá eru peir ólíklegri en ella til að upplifa tilfinningalega örmögnun og jafnframt líklegri til að upplifa ánægju í starfi (sjá til dæmis Buettner o.fl., 2016; Manlove, 1993).

Dótt mikilvægi andlegrar vellíðanar leikskólakennara fyrir gæði kennslustarfs og proska leikskólabarnanna megivera ljóst, pá hafa erlendaroginnlendar rannsóknirsýntaðleikskólakennarar finna oft fyrir streitu, örmögnun, einangrun og kulnun í starfi (Borrelli, Benevene, Fiorilli, D’Amelio og Pozzi, 2014; Kidger o.fl., 2016; McGinty, Justice og Rimm-Kaufman, 2008; Stauffer og Mason, 2013). Niðurstöður rannsóknar Gerðar Ólínu Steinpórsdóttur, Amalíu Björnsdóttur og Barkar Hansen (2015) sýna að allmargir grunn- og leikskólastjórar eiga við kulnun að stríða, bæði persónu- og starfstengda, sem og kulnun tengda starfsfólki. Kulnunin er mun algengari meðal stjórnenda leikskóla en grunnskóla. Fram kemur að priðjungur stjórnenda leikskólanna upplifir töluvert mikla líkamlega og andlega preytu og örmögnum, ekki einungis gagnvart starfi sínu sem stjórnendur, heldur einnig í samskiptum við starfsfólk sitt.

Detta er bagalegt, pví slæm líðan kennara getur haft margvíslegar neikvæðar afleiðingar í för með sér, ekki einungis fyrir kennarann sjálfan heldur einnig fyrir skólann og nemendur hans, sem og fyrir samfélagið í heild (Borrelli o.fl., 2014; Kidger o.fl., 2016; Travers og Cooper, 1996). Í pví ljósi og í ljósi niðurstaðna eigindlegrar rannsóknar Laufeyjar Axelsdóttur og Gyðu Margrétar Pétursdóttur (2014) um neikvæð áhrif efnahagshrunsins 2008 á leikskólakennarastarfið 
var ákveðið að skoða með megindlegum aðferðum líðan leikskólakennara og leiðbeinenda tveimur, premur, fimm og sjö árum eftir hrunið. Sömu einstaklingunum var fylgt eftir í öll pessi ár og eftirfarandi rannsóknarspurning sett fram: Hvernig eru tengslin á milli vinnufyrirkomulags leikskólakennara og leiðbeinenda annars vegar og andlegrar liðanar peirra hins vegar? Stjórnað var fyrir aldri, kyni, hjúskaparstöðu, menntun og starfsaldri par sem rannsóknir hafa sýnt að slíkir lýðfræðilegir pættir geti tengst andlegri líðan kennara (Burke og Greenglass, 1996; Cairney, Boyle, Offord og Racine, 2003).

\section{Gögn og aðferð}

Greinin byggir á gögnum úr langtíma panelrannsókninni Heilsa og lỉ̇an starfsfólks sveitarfélaga, par sem sama fólkinu var fylgt eftir yfir tíma. Rannsóknin náđi til áranna 2010, 2011, 2013 og 2015 og fylgst var með mögulegum breytingum á heilsu, líðan og starfstengdum viðhorfum í kjölfar efnahagshrunsins haustið 2008. Rannsóknin var sampykkt af Vísindasiðanefnd (VSN 10-007) og tilkynnt til Persónuverndar (S4634/2010).

\section{Dátttakendur og framkvæmd}

Pátttakendur í rannsókninni komu úr 17 af 72 sveitarfélögum (fimm af höfuðborgarsvæðinu og 12 af landsbyggðinni) og náði hún til nærri helmings pess starfsfólks sem starfaði hjá íslenskum sveitarfélögum. Netföngum pátttakenda var safnað meðal forsvarsmanna pátttökusveitarfélaganna. Beiðni um pátttöku í rannsókninni var send í tölvupósti í prígang til alls starfsfólks sem var í að minnsta kosti 50\% starfshlutfalli, í upphafi árs 2010 (febrúar-apríl), á vordögum 2011 (maíjúní), í upphafi árs 2013 (febrúar-apríl) og á haustdögum 2015 (október-desember). Starfsfólk sveitarfélaganna sampykkti pátttöku í rannsókninni með pvíað opna tengil með spurningalistanum sem fylgdi í tölvupóstinum sem pað síðan fyllti út og sendi inn nafnlaust. Í tölvupóstinum var tekið fram að öllum var frjálst að hafna pátttöku í rannsókninni án útskýringa og jafnframt var hægt að sleppa pví að svara einstökum spurningum. Aftast í spurningalistanum voru fjórar spurningar sem saman mynduðu ópersónugreinanlegan kóða sem notaður var til að para saman pátttakendur milli fyrirlagna spurningalistans.

Í pessari rannsókn voru aðeins notuð svör frá leikskólakennurum og leiðbeinendum í leikskólum sem svöruðu spurningalistanum í öllum fjórum fyrirlögnunum eða samtals 480 manns, 16 körlum (3,3\%) og 464 konum (96,7\%). Í rannsókninni er ekki gerður greinarmunur á leikskólakennurum og leiðbeinendum par sem gögnin buðu ekki upp á slíka aðgreiningu. Rúm 57\% pátttakenda komu frá sveitarfélögum af höfuðborgarsvæðinu og tæp 43\% frá sveitarfélögum utan höfuðborgarsvæðisins. Árið 2010, pegar spurningalistinn var lagður fyrir í fyrsta sinn, störfuðu 195 karlar í 168 stöðugildum hjá leikskólum sveitarfélaganna og 4.579 konur í 3.967 stöðugildum (Hagstofa Íslands, 2018). Hlutfall karla af starfsfólki hjá leikskólum sveitarfélaganna var pví 4,1\% árið 2010 eða aðeins hærra hlutfall en karlkynspátttakendur voru í pessari rannsókn. Í langflestum tilvikum höfðu pátttakendur lokið háskólaprófi eða 68,9\%, 14,6\% höfðu lokið framhaldsskólaprófi og 16,5\% grunnskólaprófi. Allt var petta pó starfsfólk sem kom að uppeldi og menntun leikskólabarnanna.

\section{Mælikvarðar og úrvinnsla}

Andleg líðan var mæld með sjö staðhæfingum; (1) „Ég hef litið bjartsýnum augum til framtíðarinnar“, (2) „Mér hefur pótt ég gera gagn“, (3) „Ég hef verið afslöppuð/afslappaður“, (4) „Mér hefur gengið vel að takast á við vandamál“, (5) „Ég hef hugsað skýrt““, (6) „Mér hefur fundist ég náin(n) öðrum“ og (7) „Ég hef átt auðvelt með að gera upp hug minn“. Svarmöguleikar fyrir pessar sjö staðhæfingar voru frá (1) mjög oft eða alltaf að (5) mjög sjaldan eða aldrei. Detta pýðir að eftir pví sem gildið er hærra er minni vellíðan (Cronbach’s alpha=0,917). 
Vinnuumhverfið var skoðað út frá upplifun leikskólakennara á sex páttum; (1) stjórnun vinnustaðarins, (2) félagslegum stuðningi yfirmanna, (3) félagslegum stuðningi vinnufélaga, (4) álagi í starfi, (5) óskýru hlutverki í starfi og (6) próun í starfi.

(1) Upplifun og viðhorf til stjórnunar vinnustaðarins var metin með premur spurningum og einni staðhæfingu; (a) „Hvetur næsti yfirmaður pinn pig til að taka pátt í mikilvægum ákvörðunum?“, (b) „Útdeilir næsti yfirmaður pinn verkefnum á hlutlægan og réttlátan hátt?“, (c) „Gætir næsti yfirmaður pinn réttlætis og jafnræðis í framkomu sinni við starfsmenn?“ og (d) „Degar á heildina litið er ég ánægð(ur) með stjórnun vinnustaðarins“. Svarmöguleikarnir voru frá (1) mjög oft eða alltaf að (5) mjög sjaldan eða aldrei. Pannig sýnir hærra gildi minni ánægju með stjórnun vinnustaðarins (Cronbach's alpha $=0,855)$.

(2) Upplifun á félagslegum stuðningi frá yfirmönnum var mældur með tveimur spurningum; (a) „Færð pú stuðning og hjálp með verkefni hjá næsta yfirmanni pínum, ef á parf að halda?“ og (b) „Er næsti yfirmaður pinn fús til að hlusta á vandamál sem við er að glíma í vinnunni, ef á parf að halda?" Svarmöguleikarnir voru frá (1) mjög oft eða alltaf að (5) mjög sjaldan eða aldrei. Hærra gildi pýðir upplifun á minni stuðningi frá yfirmönnum (Cronbach’s alpha=0,859).

(3) Upplifun á félagslegum stuðningi frá vinnufélögum var mæld með tveimur spurningum; (a) „Færð pú stuðning og hjálp með verkefni hjá vinnufélögum pínum, ef á parf að halda?“ og (b) „Eru vinnufélagarnir fúsir til að hlusta á vandamál sem við er að glíma í vinnunni, ef á parf að halda?" Svarmöguleikarnir voru frá (1) mjög oft eða alltaf að (5) mjög sjaldan eða aldrei pannig að hærra gildi pýðir minni upplifun á félagslegum stuðningi frá vinnufélögum. (Cronbach’s alpha $=0,819)$.

(4) Upplifun á álagi í starfi var mæld með premur spurningum; (a) „Er vinnuálag svo ójafnt að verkefnin hlaðist upp?“”, (b) „Verður pú að vinna á miklum hraða?“” og (c) „Hefur pú of mikið að gera?“ Svarmöguleikarnir voru frá (1) mjög sjaldan eða aldrei að (5) mjög oft eða alltaf. Hærra gildi pýðir upplifun á meira álagi í starfi (Cronbach’s alpha=0,805).

(5) Óskýrt hlutverk í starfi var metið með premur spurningum; (a) „Verður pú að gera eitthvað sem pér finnst að ætti að gera öðruvísi?“, (b) „Færð pú verkefni til að leysa án pess að hafa nauðsynleg bjargrád til pess?“ og (c) „Gera tveir eða fleiri ósamræmanlegar kröfur til pín?““ Svarmöguleikarnir voru frá (1) mjög sjaldan eða aldrei að (5) mjög oft eða alltaf. Hærra gildi pýðir pví meiri upplifun á óskýrum hlutverkum í starfi (Cronbach’s alpha=0,739).

(6) Dróun í starfi var metin með tveimur staðhæfingum; (a) „Ég er í góðri aðstöðu til pess að proskast í starfi“, (b) „Ég tel mig eiga góða möguleika á starfsframa á vinnustaðnum“. Dessar staðhæfingar voru mældar á fimm prepa Likert-kvarða par sem (1) var mjög sammála og (5) mjög ósammála. Hærra gildi segir til um minni möguleika á próun í starfi (Cronbach's alpha=0,638).

Faglegur bakgrunnur var mældur með tveimur spurningum. Í fyrsta lagi; „Hvaða menntun hefur pú?"“Svörin voru flokkuð í fjóra flokka; grunnskólamenntun, framhaldsskólamenntun, fyrstu háskólagráđu og framhaldsnám á háskólastigi. Ekki var spurt sérstaklega um hvort um B.Ed.- eða M.Ed.-gráðu var að ræða. Í öðru lagi; „Hve lengi hefur pú starfað á núverandi vinnustað?“ Svör voru flokkuð í prjá flokka, 5 ár eða skemur, 6 til 10 ár og 11 ár eða lengur.

Auk pess voru gögnin greind eftir aldri (aldur í árum), kynferði (karl/kona) og hjúskaparstöðu (einhleypur/hjónaband eða í sambúð).

Niðurstöðurnar voru settar fram sem hlutfallstölur, meðaltöl, staðalfrávik, fylgnistuðlar og hlutfallslíkur. Notuð var einföld dreifigreining fyrir endurteknar mælingar til að skoða andlega líðan og pætti í vinnuumhverfinu (stjórnun vinnustaðarins, félagslegan stuðning yfirmanna og vinnufélaga, vinnuálag, óskýr hlutverk og próun í starfi) yfir tíma. Til að skoða fylgni milli andlegrar líðanar og vinnufyrirkomulagsins var notast við Pearsons's R-fylgnipróf. Stuðst var við 
skilgreiningu Cohens (1988, bls. 79-81) til að meta hvort um veik (0,10-0,29), miðlungssterk $(0,30-0,49)$ eða sterk tengsl $(0,50-1,0)$ væri að ræða. Til að spá um líkur á andlegri vanlíðan með tilliti til tíma, kyns, aldurs, hjúskaparstöðu, faglegs bakgrunns (menntun og starfsaldur) og vinnuumhverfis var notað GEE-tölfræðilíkan (e. generalized estimating equation). Slíkt líkan hentar vel til pess að greina langtímagögn, einkum vegna pess að pað notar alla tiltæka mælipunkta, meðhöndlar fylgni endurtekinna mælinga og reiknar hvernig mynstrið í gögnunum breytist á milli fyrirlagna. Sett voru fram prjú líkön; (1) áhrif kyns, aldurs og hjúskaparstöðu á andlega vellíðan, (2) líkan 1 plús áhrif faglegs bakgrunns á andlega vellíðan og (3) líkan 2 plús áhrif vinnuumhverfis á andlega vellíðan. Settar voru fram hlutfallslíkur, 95\% öryggisbil og marktæknistuðlar fyrir alla pætti sem tekið var tillit til. Tölfræði var unnin í SPSS 22 og marktæknikrafa var 0,05 .

\section{Niðurstöður}

Í töflu 1 má sjá að leikskólakennarar og leiðbeinendur í rannsókninni voru á aldrinum 26 til 69 ára og meðalaldurinn tæp 48 ár. Eins og við var að búast voru karlar í miklum minnihluta og var meðalaldur peirra nokkuð lægri en kvenna, eða rúm 42 ár á móti tæpum 48 árum. Vegna pess hve fáir karlarnir voru, var leiðrétt fyrir kynjamun í flestum tilfellum, fremur en að bera saman niðurstöður svara frá konum og körlum. Í langflestum tilvikum voru leikskólakennararnir og leiðbeinendurnir í hjónabandi eða sambúð (82\%) og með háskólamenntun (69\%), par af rúm 14\% með framhaldsnám á háskólastigi. Rétt rúmlega priðjungur hafði starfað í 5 ár eða skemur á vinnustaðnum og rétt rúm 38\% í 11 ár eða lengur.

Tafla 1. Bakgrunnur pátttakenda, menntun og aldur

\begin{tabular}{lcc}
\hline Breytur & $\mathbf{N}$ & \\
\hline Lýðfræðilegar upplýsingar & & \\
Meðalaldur í árum & 480 & 47,7 \\
Konur & 464 & $96,7 \%$ \\
Karlar & 16 & $3,3 \%$ \\
Einhleyp(ur) & 89 & $18,5 \%$ \\
Í hjónabandi/sambúð & 391 & $81,5 \%$ \\
Faglegur bakgrunnur & & \\
Menntun & & \\
Grunnskóli & 79 & $16,5 \%$ \\
Framhaldsskóli & 70 & $14,6 \%$ \\
Fyrsta háskólagráða & 263 & $54,8 \%$ \\
Framhaldsnám á háskólastigi & 68 & $14,1 \%$ \\
Starfsaldur & & \\
5 ár eða skemur & 163 & $34,0 \%$ \\
6-10 ár & 132 & $27,6 \%$ \\
11 ár eða lengur & 184 & $38,4 \%$ \\
\hline
\end{tabular}


Tafla 2 sýnir breytingar á andlegri líðan og páttum í vinnuumhverfinu (stjórnun vinnustaðarins, félagslegum stuðningi frá yfirmönnum og vinnufélögum, álag í starfi, óskýr hlutverk og bróun í starfi) á árunum 2010, 2011, 2013 og 2015. Dreifigreining fyrir endurteknar mælingar sýndi að sjálfmetin andleg líðan leikskólakennaranna og leiðbeinendanna versnaði ár frá ári, mest pó á milli fyrirlagnanna $2011(\mathrm{M}=2,13, \mathrm{sf}=0,6)$ og $2013(\mathrm{M}=2,22, \mathrm{sf}=0,7)$. Allir pættir í vinnuumhverfinu sem til skoðunar voru versnuðu einnig milli fyrirlagna. Sá páttur sem breyttist mest var vinnuálag en í fyrirlögninni árið 2010 mátu leikskólakennararnir og leiðbeinendurnir vinnuálagið 2,60 á skalanum 1-5, en í fyrirlögninni 2015 var pað komið í 3,04. Næst mesta breytingin var á próun í starfi en meðaltalið fyrir pann pátt hækkaði úr 2,27 í fyrirlögninni árið 2010 í 2,57 árið 2015. Sjá mátti að vinnuálagið jókst mest á milli fyrirlagnanna 2013 og 2015 á meðan pættir eins og félagslegur stuðningur yfirmanna og samstarfsfólks og próun í starfi minnkaði meira á milli fyrirlagnanna 2010 og 2011 heldur en á milli annarra fyrirlagna. Sjá nánar töflu 2.

Tafla 2. Breyting á andlegri líðan leikskólakennara og leiðbeinenda og pátta í vinnuumhverfinu á rannsóknartímabilinu

\begin{tabular}{|c|c|c|c|c|c|}
\hline Breytur & $N$ & $M(s f) 2010-2011-2013-2015^{\star}$ & Spönn & Fj. sp. & $\alpha$ \\
\hline Andleg líðan ${ }^{1}$ ) & 480 & $2,08(0,6)-2,13(0,6)-2,22(0,7)-2,21(0,7)$ & $1-5$ & 7 & 0,917 \\
\hline $\begin{array}{l}\text { Stjórnun } \\
\text { vinnustaðarins }{ }^{2} \text { ) }\end{array}$ & 477 & $2,04(0,9)-2,14(0,8)-2,16(0,9)-2,12(0,9)$ & $1-5$ & 4 & 0,855 \\
\hline $\begin{array}{l}\text { FS } \star \star \\
\left.\text { yfirmanna }{ }^{3}\right)\end{array}$ & 477 & $1,74(0,9)-1,89(0,9)-1,89(0,9)-1,94(0,9)$ & $1-5$ & 2 & 0,859 \\
\hline $\begin{array}{l}\mathrm{FS} \star \star \\
\text { samstarfsfólks }{ }^{4} \text { ) }\end{array}$ & 477 & $1,74(0,8)-1,82(0,8)-1,90(0,8)-1,92(0,8)$ & $1-5$ & 2 & 0,819 \\
\hline Vinnuálag $\left.{ }^{5}\right)$ & 480 & $2,60(0,8)-2,71(0,8)-2,81(0,8)-3,04(0,8)$ & $1-5$ & 3 & 0,805 \\
\hline Óskýr hlutverk ${ }^{6}$ ) & 477 & $2,03(0,8)-2,05(0,8)-2,14(0,8)-2,18(0,8)$ & $1-5$ & 3 & 0,739 \\
\hline Próun í starfi ${ }^{7}$ ) & 477 & $2,27(0,9)-2,39(0,9)-2,50(0,9)-2,57(0,9)$ & $1-5$ & 2 & 0,638 \\
\hline
\end{tabular}

$\star$ Hærri tala gefur til kynna aukningu frá fyrra tímabili

$\star \star$ FS $=$ Félagslegur stuðningur

$\left.{ }^{1}\right)$ Wilks' Lambda $=0,91, F(3,477)=9,11, p<0,001$, multivariate partial eta squared $=0,05$

$\left.{ }^{2}\right)$ Wilks' Lambda $=0,98, F(3,474)=3,36, p<0,005$, multivariate partial eta squared $=0,02$

$\left.{ }^{3}\right)$ Wilks' Lambda $=0,96, F(3,474)=6,84, p<0,001$, multivariate partial eta squared $=0,04$

$\left.{ }^{4}\right)$ Wilks' Lambda $=0,96, F(3,474)=7,09, p<0,001$, multivariate partial eta squared $=0,04$

$\left.{ }^{5}\right)$ Wilks' Lambda $=0,78, F(3,477)=44,57, p<0,005$, multivariate partial eta squared $=0,22$

$\left.{ }^{6}\right)$ Wilks' Lambda $=0,96, F(3,474)=7,08, p<0,001$, multivariate partial eta squared $=0,04$

${ }^{7}$ ) Wilks' Lambda $=0,90, F(3,474)=17,40, p<0,001$, multivariate partial eta squared $=0,10$

Skoðuð var fylgni milli andlegrar líðanar leikskólakennaranna og leiðbeinenda og peirra sex pátta í vinnuumhverfinu sem koma fram í töflum 2 og 3. Niðurstöðurnar í töflu 3 sýna jákvæð miðlungssterk tengsl milli andlegrar líðanar og stjórnunar vinnustaðarins $(r=0,33)$, félagslegs stuðnings yfirmanna $(r=0,31)$ og félagslegs stuðnings samstarfsfólks $(r=0,30)$. Með öðrum orðum, eftir pví sem upplifun leikskólakennaranna og leiðbeinenda á stjórnun vinnustaðarins var verri og upplifun peirra á félagslegum stuðningi frá yfirmanni og samstarfsfólki var minni, peim mun verr leið starfsfólkinu. Sterkust voru tengslin á milli félagslegs stuðnings samstarfsfólks og yfirmanna $(r=0,72)$. Баð ber vott um að ef sú upplifun var fyrir hendi að starfsfólkið fékk félagslegan stuðning, pá var stuðninginn að finna bæði frá stjórnendum og samstarfsfólki. Баð kemur pví ekki á óvart pótt einnig hafi verið sterk jákvæð tengsl á milli félagslegs stuðnings 
samstarfffólks og jákvæðrar upplifunar á stjórnun vinnustaðarins $(r=0,64)$. Ef vinnustaðnum var vel stjórnað að mati leikskólakennaranna og leiðbeinendanna, pá voru jafnframt meiri líkur á félagslegum stuðningi af hálfu starfsfólksins. Vinnuálag var sá páttur í vinnuumhverfinu sem hafði minnstu tengslin við andlega líðan $(r=0,16)$ og jafnframt sá páttur sem hafði lítil tengsl við aðra pætti í vinnuumhverfinu, ef frá eru talin óskýr hlutverk $(r=0,38)$. Eftir pví sem álagið var meira, peim mun sterkari var tilfinningin um óskýr hlutverk. Einnig kom fram að eftir bví sem tilfinningin um óskýr hlutverk var meiri, pví meiri andlega vanlíðan upplifðu leikskólakennarar og leiðbeinendur $(r=0,29)$, peir voru óánægðari með stjórnun vinnustaðarins $(r=0,39)$ og upplifðu jafnframt minni félagslegan stuðning frá yfirmönnum $(r=0,38)$ og samstarfsfólki $(r=0,38)$. Niðurstöðurnar sýndu einnig jákvæð tengsl milli próunar 1 starfi og andlegrar vellíðanar $(r=0,26)$, pannig að meiri ánægja með starfspróun hafði tengsl við betri andlega líðan leikskólakennara og leiðbeinenda. Deir leikskólakennarar og leiðbeinendur sem voru ánægðir með próun í starfi voru einnig ánægðir með stjórnun vinnustaðarins $(r=0,36)$ og upplifðu meiri félagslegan stuðning frá yfirmönnum $(r=0,31)$ og samstarfsfólki $(r=0,34)$ en aðrir. Sjá nánar töflu 3.

Tafla 3. Pearson's R-fylgni milli andlegrar líðanar leikskólakennara og leiðbeinenda annars vegar og pátta í vinnuumhverfinu hins vegar

\begin{tabular}{lllllllll}
\hline Breytur & $\mathbf{1}$ & $\mathbf{2}$ & $\mathbf{3}$ & $\mathbf{4}$ & $\mathbf{5}$ & $\mathbf{6}$ & $\mathbf{7}$ \\
\hline 1. Andleg líðan & - & & & & & & \\
2. Stjórnun vinnustaðarins & $0,329 \star$ & - & & & & & \\
3. Félagslegur stuðningur yfirmanna & $0,309 \star$ & $0,474 \star$ & - & & & & \\
4. Félagslegur stuðningur samstarfsfólks & $0,302^{\star}$ & $0,641 \star$ & $0,715^{\star}$ & - & & & \\
5. Vinnuálag & $0,155^{\star}$ & $0,161^{\star}$ & $0,180^{\star}$ & $0,194 \star$ & - & & \\
6. Óskýr hlutverk & $0,287 \star$ & $0,391 \star$ & $0,347 \star$ & $0,377 \star$ & $0,381 \star$ & - & \\
7. Próun í starfi & $0,256^{\star}$ & $0,359 \star$ & $0,312 \star$ & $0,342 \star$ & $0,135^{\star}$ & $0,265^{\star}$ & - \\
\hline
\end{tabular}

$\star p<0,001$

Til pess að spá fyrir um andlega líðan leikskólakennara og leiðbeinenda var notað GEE-líkan par sem tekið var tillit til lýðfræðilegs bakgrunns, faglegs bakgrunns og pátta í vinnuumhverfinu yfir tíma (tafla 4). Niðurstöður líkans 1 sýna marktæka versnun andlegrar líðanar yfir tíma að teknu tilliti til kyns, aldurs og hjúskaparstöðu en einnig má sjá marktækt verri andlega líðan peirra sem eru í hjónabandi eða sambúð en peirra sem eru einhleypir $(\mathrm{OR}=1,16)$ að teknu tilliti til tíma, kyns og aldurs. Líkan 2 sýnir marktækt verri andlega líðan yfir tíma að teknu tilliti til annarra pátta í líkaninu en einnig að andleg líðan peirra leikskólakennara og leiðbeinenda, sem höfðu háskólapróf, var betri en peirra sem voru aðeins með grunnskólamenntun $(\mathrm{OR}=0,95)$, að teknu tilliti til annarra pátta í líkaninu. Sjá má í líkani 3 að allir pættir í vinnuumhverfinu nema vinnuálag og stuðningur yfirmanna höfðu marktæk áhrif á andlega líðan leikskólakennara og leiðbeinenda, að teknu tilliti til annarra pátta í líkaninu. Баð pýðir að eftir pví sem upplifun og viðhorf til stjórnunar vinnustaðarins voru verri, upplifun af félagslegum stuðningi frá samstarfsfólki var minni, hlutverk voru óskýrari og ánægja með próun í starfi var minni, peim mun verri var andleg líðan starfsfólksins yfir tíma, að teknu tilliti til lýðfræðilegs og faglegs bakgrunns pátttakenda. Skortur á félagslegum stuðningi samstarfsfólks var sá páttur sem hafði hæsta forspárgildið fyrir andlega vanlíðan $(\mathrm{OR}=1,14)$. Einnig sýndu niðurstöður líkans 3 betri líðan háskólamenntaðra og peirra sem eldri voru að teknu tilliti til tíma, kyns, starfsaldurs og vinnufyrirkomulags. 
Tafla 4. GEE-líkan til að spá fyrir um líkur á andlegri vanlíðan leikskólakennara og leiðbeinenda

\begin{tabular}{|c|c|c|c|c|c|c|}
\hline & \multicolumn{2}{|l|}{ Líkan 1} & \multicolumn{2}{|l|}{ Líkan 2} & \multicolumn{2}{|l|}{ Líkan 3} \\
\hline & OR & 95\% C.I. & OR & 95\% C.I. & OR & 95\% C.I. \\
\hline Fasti & $9,34 \star \star \star$ & $6,45-13,51$ & $9,60 \star \star \star$ & $6,48-14,23$ & $4,01 \star \star \star$ & $2,74-5,88$ \\
\hline Önnur fyrirlögn & $1,05^{\star}$ & $0,99-1,10$ & $1,05^{\star}$ & $1,00-1,10$ & 1,02 & $0,97-1,07$ \\
\hline Priðja fyrirlögn & $1,15^{\star \star \star}$ & $1,09-1,22$ & $1,17 \star \star \star$ & $1,10-1,24$ & $1,10 \star \star$ & $1,03-1,16$ \\
\hline Fjórða fyrirlögn & $1,14 \star \star \star$ & $1,06-1,22$ & $1,16^{\star \star \star}$ & $1,08-1,24$ & $1,07 \star$ & $1,00-1,15$ \\
\hline Konur & 1,05 & $0,80-1,37$ & 1,06 & $0,81-1,39$ & 1,20 & $0,95-1,51$ \\
\hline Aldur & 1,00 & $0,99-1,00$ & 1,00 & $0,99-1,00$ & $0,99 \star$ & $0,99-1,00$ \\
\hline Í hjónabandi eða sambúð & $1,16^{\star \star}$ & $1,03-1,30$ & $1,14^{\star}$ & $1,02-1,28$ & $1,15^{\star \star}$ & $1,04-1,28$ \\
\hline Framhaldsskólapróf & & & 0,95 & $0,84-1,06$ & 0,94 & $0,84-1,05$ \\
\hline Háskólapróf & & & $0,90 \star$ & $0,80-0,99$ & $0,88^{\star}$ & $0,80-0,98$ \\
\hline 6-10 ár & & & 0,97 & $0,89-1,06$ & 0,97 & $0,89-1,05$ \\
\hline 11 ár eða lengur & & & 0,93 & $0,84-1,02$ & 0,95 & $0,87-1,04$ \\
\hline Stjórnun vinnustaðarins & & & & & $1,11 \star \star \star$ & $1,05-1,17$ \\
\hline $\begin{array}{l}\text { Félagslegur stuðningur } \\
\text { yfirmanna }\end{array}$ & & & & & 0,98 & $0,93-1,04$ \\
\hline $\begin{array}{l}\text { Félagslegur stuðningur } \\
\text { vinnufélaga }\end{array}$ & & & & & $1,14 \star \star \star$ & $1,09-1,20$ \\
\hline Vinnuálag & & & & & 1,04 & 0,99-1,09 \\
\hline Óskýr hlutverk & & & & & $1,11 \star \star \star$ & $1,05-1,17$ \\
\hline Dróun í starfi & & & & & $1,06^{\star}$ & $1,01-1,10$ \\
\hline
\end{tabular}

Ath: ${ }^{\star \star \star} p<0.001,{ }^{\star \star} p<0.01,{ }^{\star} p<0.05$

Viðmiðunarbreytur voru: Tími: Fyrsta fyrirlögn; Kyn: karlar; Hjúskaparstaða: einhleyp(ur);

Menntun: grunnskóla-próf; Starfsaldur: 5 ár eða styttri

\section{Umræður}

Ĺððan leikskólakennara og leiðbeinenda og vinnuumhverfi peirra geturskipt miklu fyrir líðan barna í leikskólum. Meginmarkmið rannsóknarinnar, sem hér er fjallað um, var pví að skoða tengslin á milli upplifunar leikskólakennara og leiðbeinenda af tilteknum páttum vinnuumhverfisins og sjálfmetinnar andlegrar líðanar peirra, tveimur, premur, fimm og sjö árum eftir efnahagshrunið 2008. Sérstakar ástæður eru til að huga að pessum páttum í kjölfar hrunsins par sem eigindleg rannsókn Laufeyjar Axelsdóttur og Gyðu Margrétar Pétursdóttur (2014) gefur til kynna að efnahagslegur samdráttur sveitarfélaganna hafi skapað erfiðar aðstæður í leikskólunum (Laufey Axelsdóttir og Gyða Margrét Pétursdóttir, 2014). Dessi rannsókn sýnir að sjálfmetin andleg líðan leikskólakennara og leiðbeinenda hafi versnað á milli áranna 2010 og 2015 en á peim árum fækkaði menntuðum leikskólakennurum, sameining leikskóla var allnokkur, stöðugildum fækkaði en hins vegar fjölgaði leikskólabörnum. Allir pættirnir í vinnuumhverfinu sem til skoðunar voru leikskólunum versnuðu einnig að mati starfsfólksins. Sá páttur, sem versnaði mest, var vinnuálag. Athyglisvert er pó að tengslin voru veik á milli vinnuálags og versnandi andlegrar líðanar sem pýðir að aðrir pættir í vinnuumhverfinu hafa meiri áhrif á andlega líðan leikskólakennara og leiðbeinenda. Velta má vöngum yfir pví hvort leikskólakennarar og leiðbeinendur hafi bjargráð til að draga úr áhrifum vinnuálags. 
Dar sem í ljós kom að líðan starfsfólks leikskólanna versnaði á milli áranna 2010 og 2015, eins og áður sagði, var mikilvægt að skoða hvaða pættir höfðu forspárgildi fyrir verri andlega líðan yfir tíma, að teknu tilliti til kyns, aldurs og hjúskaparstöđu. Í ljós kom að góð stjórnun og félagslegur stuðningur samstarfsfólks hafði jákvæð áhrif á líðanina yfir tíma, að teknu tilliti til annarra pátta sem til skoðunar voru. Skýr hlutverk og möguleikar starfsfólks á að próast í stafi höfðu einnig jákvæð áhrif á líðanina en pó ekki eins mikil áhrif og góð stjórnun og stuðningur samstarfsfólks. Niðurstöður gefa pannig til kynna að við skipulag leikskólastarfsins purfi að huga sérstaklega vel að félagslegum stuðningi, hvatningu og sanngirni hvað varðar framkomu yfirmanna og útdeilingu verkefna, hversu skýr hlutverk leikskólakennarar og leiðbeinendur hafa og möguleika peirra til að proskast og próast í starfi. Sérstaklega á petta við um pá starfsmenn sem yngri eru og pá sem ekki hafa háskólamenntun. Samkvæmt Aðalnámskrá leikskóla eiga leikskólakennarar að hafa kost á pví að próast í starfi. Рað er mjög mikilvægt að starfspróun eigi sér stað innan leikskólanna pannig að leikskólakennarar og leiðbeinendur geti aukið fagmennsku sína, pekkingu og kunnáttu í peim tilgangi að veita börnum sem besta umönnun (Mennta- og menningarmálaráduneytið, 2013). Einnig má ætla að starfspróun hafi jákvæð áhrif á faglegt sjálfstraust leikskólakennara og leiðbeinenda og par með jákvæð áhrif á líðan peirra á vinnustaðnum.

Athygli vekur að starfsaldur hafði ekki forspárgildi fyrir andlega líðan leikskólakennara og leiðbeinenda en Rimm-Kaufman og Hamre (2010) og einnig Freidman-Krauss og félagar (2014) telja að með aukinni menntun og meiri starfsreynslu pá öðlist kennarar meiri hæfni til að takast á við krefjandi hegðun leikskólabarnanna og pað andlega álag sem leikskólakennarastarfinu fylgi. Dótt okkar rannsókn styðji ekki áđurnefndar niðurstöður um tengsl starfsaldurs og líðanar pá sýnir hún að háskólamenntun hafði jákvæð áhrif á andlega líðan. Pað er pví umhugsunarefni að enn skuli hlutfall ófaglærðs starfsfólks við uppeldi og menntun leikskólabarna vera eins hátt og raun ber vitni.

Drátt fyrir að hér sé fyrst og fremst varpað ljósi á tengsl vinnufyrirkomulags og vinnutengdrar líðanar starfsfólks pá er sá möguleiki fyrir hendi að sú aukna vanlíðan sem mælist í rannsókninni á árunum 2010-2015 sé vegna pátta sem liggja utan vinnustaðarins. Hér má nefna álag sem kann að hafa gert vart við sig í fjölskyldum hér á landi í kjölfar bankahrunsins, sem parf ekki аð tengjast vinnunni sem slíkri. Рað gæti m.a. skýrt hvers vegna líðanin versnaði minna milli áranna 2013 og 2015 en fyrri árin en samkvæmt opinberum gögnum (Hagstofa Íslands, 2017) hefur efnahagsástandið á Íslandi almennt batnað frá árinu 2013. Í pví ljósi er pó umhugsunarvert að andlega líðanin skuli enn versna árið 2015 og einnig viðhorfið til peirra vinnuumhverfispátta sem mældir eru.

Að meta andlega líðan starfsfólks er mikilvægt en getur jafnframt verið erfitt enda ekki til algildir mælikvarðar að styðjast við. Slíkt er mikilvægt að hafa í huga pegar gögn um sjálfmetna heilsu og orsakir hennar eru rædd (Guðbjörg Linda Rafnsdóttir og Hjördís Sigursteinsdóttir, 2016). Dví er mikilvægt að hafa í huga að ekki er hægt að vita hvort sömu einstaklingar, sem spurðir eru með einhverra ára millibili, tjái nákvæmlega sömu eða sambærilegar tilfinningar pegar peir lýsa líðan sinni. Mögulegt er að orðræðan í samfélaginu í kjölfar kreppunnar hafi hvatt starfsfólk til að upplifa og/eða tjá vanlíðan í meiri mæli en áður og að vera gagnrýnið á fyrirkomulag vinnunnar. Engu að síður er mikilvægt að skoða niðurstöðurnar í ljósi peirra skipulagsbreytinga sem hafa orðið á rekstri leikskólanna og kallað hafa fram sameiningar peirra og stækkun skipulagsheilda, og jafnframt fækkun stöðugilda. Einnig er mikilvægt að huga að peirri staðreynd að hlutfall leikskólakennara af starfsfólki í leikskólum landsins hefur lækkað og var einungis um priðjungur árið 2016 (Hagstofa Íslands, 2017). Slíkt kann að auka álag á starfsfólk leikskólanna. Pá hafa miklar breytingar átt sér stað á námi í leikskólakennarafræðum á pessu tímabili en frá árinu 2011 ljúka leikskólakennarar meistaranámi en fram að pví hafði námið verið priggja ára B.Ed-nám. Mikilvægt er að rannsaka hvaða mögulegu breytingar petta hefur haft í för með sér fyrir líðan leikskólakennara. 
Styrkur rannsóknarinnar, til viðbótar við að petta er fyrsta rannsókn sinnar tegundar hér á landi, er að hér er unnið með panelgögn par sem sömu einstaklingum er fylgt eftir tveimur, premur, fimm og sjö árum eftir bankahrunið á Íslandi haustið 2008. Auk pess telst pað styrkur að ekki var um úrtaksrannsókn að ræða heldur voru spurningalistarnir sendir til alls starfsfólks sem féll innan ramma rannsóknarinnar. Svarhlutfallið er vel ásættanlegt. Sumir kunna að líta á pað sem veikleika að niðurstöðurnar byggja á spurningalistakönnun svo að erfitt getur reynst að skilja hverju fólk raunverulega miðlar um líðan sína enda ekki til algildir mælikvarðar um sjálfmetna líðan. Dví er pó til að svara að við lítum svo á að í raun sé fátt marktækara, pegar fjallað er um heilsu og líðan, en eigin upplifun af ástandinu. Ef starfsfólk upplifir að líðan peirra og vinnuumhverfi fari versnandi, hvað svo sem annars konar mælingar kunna að leiða í ljós, pá hlýtur að purfa að taka mark á peirri upplifun. Einnig má ætla að munur geti verið á líðan eftir pví hvort viðkomandi er menntaður til leikskólastarfsins eður ei. Leikskólakennarar hafa oftar meiri ábyrgð en leiðbeinendur en pað getur haft áhrif á líðan og par af leiðandi á pað umhverfi sem börnin búa við. Gögnin, sem notuð voru í pessari rannsókn, koma úr rannsókn á heilsu, líðan og starfstengdum viðhorfum starfsfólks sveitarfélaga og pví aðeins hægt að taka út hópinn sem annast börnin í leikskólunum en ekki hvort viðkomandi hefði menntun sem leikskólakennari, aðra háskólamenntun eða væri ófaglærður starfsmaður leikskóla.

\section{Ályktun}

Niðurstöðurnar sýna að vinnufyrirkomulag og líðan leikskólakennara og leiðbeinenda hefur versnað í kjölfar hrunsins, sem gefur jafnframt vísbendingar um neikvæð áhrif á getu peirra til að takast á við starfið. Slíkt ástand getur jafnframt haft neikvæð áhrif á proskaferil og líðan leikskólabarnanna. Niðurstöðurnar hljóta pví að vera talsvert áhyggjuefni. Mikilvægt er að stjórnvöld, stjórnendur og starfsfólk leikskólanna hugi vel að pví hvernig snúa megi við blaðinu svo að hægt sé að efla innra starf leikskólanna, og gera par með einnig vinnuumhverfi leikskólabarnanna pannig úr garði að tryggja megi peim góða umönnun og menntun. Pað felur meðal annars í sér að vinna að hvetjandi stjórnunarháttum, félagslegum stuðningi og möguleikum til starfspróunar, par sem pessir pættir stuðla að vellíðan starfffólksins og draga úr neikvæðum áhrifum vinnuálags. Ályktun okkar er sú að verði svo gert pá muni pað jafnframt skila sér í betra námsumhverfi fyrir leikskólabörnin. 


\section{The well-being of preschool and assistant teachers in the wake of the economic collapse}

The well-being and working conditions of preschool teachers and assistant teachers can affect children and their developmental processes, as they spend so many hours together every week. The social-emotional capacity and the psychological wellbeing of preschool and assistant teachers are fundamental characteristics that support improved social and emotional learning practices in the classroom. Preschool teachers and assistant teachers who experience emotional exhaustion and burnout at work are less likely to exhibit positive practices in children's caregiving. This a major concern, since teaching is often recognized as one of the most stressful occupations. Although interest in preschool and assistant teachers' own psychological well-being and selfcare is growing, more research is needed to understand the state of their well-being to find ways to better support their mental health. Therefore, in the current study, we explore factors in the work environment that support or reduce the well-being of preschool and assistant teachers, such as management, social support at work, workload, job roles and job development. We studied the work conditions and connections between work environment and self-evaluated mental well-being of approximately half of all preschool teachers and assistant teachers in Iceland - in seventeen out of the seventy-two municipalities in Iceland. The past decade has seen considerable changes in the work environment of municipal employees, which can be traced to the economic collapse in 2008. These changes are reflected in, among other things, mergers of preschools and a decrease in numbers of preschool teachers and assistant teachers while the proportion of children attending preschool has increased. In 2009, there were 284 preschools in Iceland but in 2016, they were only 254. However, the proportion of children attending preschools has risen, from $82 \%$ to $86 \%$ while the number of preschool and assistant teachers has decreased by 2\% between 2014 and 2016. The aim of the study is to assess the relationship between preschool and assistant teachers' well-being and work environment over time. The research is based on longterm panel data and responses from 480 preschool teachers and assistant teachers in the years 2010, 2011, 2013 and 2015, where the same individuals are followed. A Generalized Estimating Equation (GEE) model was used to predict the mental health of the employees during these years. Repeated measurements showed that the preschool and assistant teachers' self-valuated mental well-being worsened between each study point of the questionnaire. This also occurred when the background factors of gender, age and marital status had been taken into account. All aspects of the working environment under scrutiny (management, social support, workload, job roles and job development) also deteriorated in the opinion of the preschool and assistant teachers participating in the study. The factor that worsened most was the workload. Interestingly, however, the relationship was weak between workload and mental well-being. Good management and social support had a positive effect on well-being. It is important that those who are responsible for preschool teachers and assistant teachers' well-being consider these results and further analyse the causes of worsening work environment factors and the self-rated well-being of preschool and assistant teachers, two, three, five and seven years after the economic collapse in 2008. The results of the study indicate that if nothing is done to improve the work environment, self-rated mental distress may increase. It is, therefore, essential to pay close attention to factors like motivation and support from superiors, social support, and opportunity for job development, as these factors enhanced the well-being of preschool and assistant teachers. In our opinion, this will lead to a better study environment and help to to ensure excellent care and education for the children.

Key words: Mental health, social support, kindergarten employees, management, workload, work organization, working invironment. 


\section{Um höfundana}

GuðbjörgLinda Rafnsdóttir(glr@hi.is) er erprófessorífélagsfræðivið Félagsvísindasvið Háskóla Îslands og aðstoðarrektor vísinda. Hún er jafnframt samstarfsaðili Center for Research on Gender in the Professions við Kaliforníuháskólann í San Diego (UCSD). Áður starfaði hún á rannsóknardeild Vinnueftirlitsins. Hún lauk meistaraprófi frá háskólanum í Lundi, Svíbjóð árið 1990 og doktorsprófi frá sama háskóla árið 1995. Rannsóknir Guðbjargar Lindu hafa að mestu beinst að ýmsum sviðum atvinnulífsins, svo sem vinnutengdri heilsu og líðan, samspili fjölskyldu og atvinnulífs og lagskiptingu vinnumarkaðarins meðal annars með tilliti til kyns, pjóðernis og starfsstéttar.

Hjördís Sigursteinsdóttir (hjordis@unak.is) er dósent við Viðskipta- og raunvísindasvið Háskólans á Akureyri. Hún lauk meistaraprófi frá Háskóla Íslands árið 2008 og doktorsprófi frá sama skóla ári 2017. Áhersla í rannsóknum Hjördísar er á heilsu og líðan á vinnustað, starfstengd viðhorf og kynjamun.

\section{About the authors}

Guðbjörg Linda Rafnsdóttir (glr@hi.is) is a professor of sociology at the University of Iceland and pro-rector of science. She is affiliated at the Center for Research on Gender in the Professions, University of California San Diego (UCSD). Before that, she was a senior researcher at the Research Centre for Occupational Health and Working Life in Iceland. She has a PhD in sociology from the University of Lund, Sweden (1995) and an M.A. in sociology from the same university. Her main research topics are different aspects of working life, such as occupational health and wellbeing, work-life balance, gender, nationality and class.

Hjördís Sigursteinsdóttir (hjordis@unak.is) is an associate professor at the University of Akureyri, School of Business and Science. She has an M.A. in sociology from the University of Iceland (2008) and a PdD in sociology from the same university. Her research focus is on health and well-being at work, work-related attitude and gender.

\section{Heimildir}

Anna Póra Baldursdóttir. (2002). Kennarar og kulnun. Uppeldi og menntun, 11, 171-190.

Bloom, P.J. (1988). Factors influencing overall job satisfaction and organizational commitment in early childhood work environments. Journal of Research in Childhood Education, 3(2), 107-122. doi:10.1080/02568548809594933

Borrelli, I., Benevene, P., Fiorilli, C., D’Amelio, F. og Pozzi, G. (2014). Working conditions and mental health in teachers: A preliminary study. Occupational Medicine, 64(7), 530-532. doi:10.1093/occmed/kqu108

Buettner, C. K., Jeon, L., Hur, E. og Garcia, R. E. (2016). Teachers' social-emotional capacity: Factors associated with teachers' responsiveness and professional commitment. Early Education E Development, 27(7), 1018-1039. doi:10.1080/10409289.2016.1168227

Burchinal, M. R., Howes, C., Pianta, R. C., Bryant, D., Early, D., Clifford, R. og Barbarin, O. (2008). Predicting child outcomes at the end of kindergarten from the quality of pre-kindergarten teacher-child interactions and instruction. Applied Developmental Science, 12(3), 140-153. doi:10.1080/10888690802199418

Burke, R.J. og Greenglass, E. (1996).Work stress, social support, psychological burnout and emotional and physical well-being among teachers. Psychology, Health \& Medicine, 1(2), 193-205. doi:10.1080/13548509608400018

Cairney, J., Boyle, M., Offord, D. R. og Racine,Y. (2003). Stress, social support and depression in single and married mothers. Social Psychiatry and Psychiatric Epidemiology, 38(8), 442-449. doi:10.1007/s00127-0030661-0

Cohen, J. W. (1988). Statistical power analysis for the behavioral science (2. útgáfa). Hillsdale, NJ: Lawrence Erlbaum Associates. 
Demerouti, E., Bakker, A. B., Nachreiner, F. og Schaufeli,W. B. (2001). The job demands-resources model of burnout. Journal of Applied Psychology, 86(3), 499-512. doi:10.1037/0021-9010.86.3.499

Doi,Y. (2005). An epidemiologic review on occupational sleep research among Japanese workers. Industrial Health, 43(1), 3-10. doi:10.2486/indhealth.43.3

Fantuzzo, J., Perlman, S., Sproul, F., Minney, A., Perry, M. A. og Li, F. (2012). Making visible teacher reports of their teaching experiences: The Early Childhood Teacher Experiences Scale. Psychology in the Schools, 49(2), 194-205. doi:10.1002/pits.20623

Friedman-Krauss, A. H., Raver, C. C., Morris, P. A. og Jones, S. M. (2014). The role of classroom-level child behavior problems in predicting preschool teacher stress and classroom emotional climate. Early Education \& Development, 25(4), 530-552. doi:10.1080/10409289.2013.817030

Gerður Ólína Steinpórsdóttir, Amalía Björnsdóttir og Börkur Hansen. (2015). Grunn- og leikskólastjórar á Íslandi - kulnun í starfi? Uppeldi og menntun, 24(2), 33-56. Sótt af http://timarit.is/view_page_init. jsp?gegnirld $=001409785$

Giorgi, G., Arcangeli, G., Perminiene, M., Lorini, C., Ariza-Montes, A., Fiz Pérez, J., . . Mucci, N. (2017). Work-related stress in the banking sector: A review of incidence, correlated factors and major consequences. Frontiers in Psychology, 8, 2166. doi:10.3389/fpsyg.2017.02166

Guðbjörg Linda Rafnsdóttir. (2001). Illt er að selja sál fyrir auð. Um vinnuskipulag og líðan starfsmanna. Gedvernd, 30(1), 20-22. Sótt af http://www.hirsla.lsh.is/1sh/handle/2336/97499

Guðbjörg Linda Rafnsdóttir og Hjördís Sigursteinsdóttir. (2016). Veikindafjarvistir, læknisheimsóknir og vinnutengd líðan í kjölfar bankahruns - samanburður á starfsfólki skóla og öðru starfsfólki sveitarfélaga. Netla - Veftímarit um uppeldi og menntun. Sótt af http://netla.hi.is/greinar/2013/ryn/08_ryn_arsrit_2016.pdf

Guðbjörg Linda Rafnsdóttir og Kristinn Tómasson. (2004). Einelti á vinnustað, vinnuskipulag og líðan starfsmanna. Laknablaðið, 90(12), 847-851. Sótt af http://www.laeknabladid.is/2004/12/nr/1773

Guðmundur Ingi Guðmundsson og Guðbjörg Linda Rafnsdóttir. (2010). Starfsánægja framhaldsskólakennara. Innri og ytri áhrifapættir. Uppeldi og menntun, 19(2) , 114-129.

Gunnlaugsson, G. (2016). Child health in Iceland before and after the economic collapse in 2008. Archives of Disease in Childhood, 101(5), 489-496 [published first online 15 October 2015]. doi:10.1136/archdischild-2014-307196

Hagstofa Íslands. (2017, 21. september). Leikskólabörnum og starfsfólki á leikskólum fækkar. Sótt af https:// www.hagstofa.is/utgafur/frettasafn/menntun/leikskolar-2016/

Hagstofa Íslands. (2018). Starfsfólk í leikskólum eftir kyni, starfssviði og rekstraraðilum 1998-2017. Sótt af http://px.hagstofa.is/pxis/pxweb/is/Samfelag/Samfelag_skolamal_1_leikskolastig_1_lsStarfsfolk/ SKO01321.px/

Hall-Kenyon, K. M., Bullough, R.V., Jr., MacKay, K. L. og Marshall, E. E. (2014). Preschool teacher well-being: A review of the literature. Early Childhood Education Journal, 42(3), 153-162. doi:10.1007/s10643-013-05954

Hamre, B. K. og Pianta, R. C. (2001). Can instructional and emotional support in the first-grade classroom make a difference for children at risk of school failure? Child Development, 76(5), 949-967. doi:10.1111/ j.1467-8624.2005.00889.x

Hestenes, L. L., Kontos, S. og Bryan, Y. (1993). Children's emotional expression in childcare centers varying in quality. Early Childhood Research Quarterly, 8, 295-307. doi:10.1016/S0885-2006(05)80069-9

Hjördís Sigursteinsdóttir. (2017). Einelti, áreitni og ofbeldi á vinnustað. Könnun meðal félagsmanna Kennarasambands Íslands. Ráđstefnurit Netlu 2017 - Menntakvika. Sótt af http://netla.hi.is/serrit/2017/ menntakvika2017/006.pdf

Hjördís Sigursteinsdóttir, Guðbjörg Linda Rafnsdóttir og Guðbjörg Andrea Jónsdóttir. (2017). Changes in occupational mental and physical health and health symptoms during the economic recession. Work, 56(4), 603-615. doi:10.3233/WOR-172523

Hjördís Sigursteinsdóttir, Guðbjörg Linda Rafnsdóttir og Porgerður Einarsdóttir. (2011). „Rosaleg óvissa hjá okkur og vondur tími“. Um starfsöryggi og líðan kennara eftir hrun. Rádstefnurit Netlu-Menntakvika 2011. Sótt af http://netla.hi.is/menntakvika2011/014.pdf 
Jennings, P. A. (2015). Early childhood teachers' well-being, mindfulness, and self-compassion in relation to classroom quality and attitudes towards challenging students. Mindfulness, 6(4), 732-743. doi:10.1007/ s12671-014-0312-4

Jennings, P.A. og Greenberg, M.T. (2009). The prosocial classroom:Teacher social and emotional competence in relation to student and classroom outcomes. Review of Educational Research, 79(1), 491-525. doi:10.3102/ 0034654308325693

Karanika-Murray, M. og Weyman, A. K. (2013). Optimising workplace interventions for health and well-being: A commentary on the limitations of the public health perspective within the workplace health arena. International Journal of Workplace Health Management, 6(2), 104-117. doi:10.1108/IJWHM-11-2011-0024

Kelloway, E. K. (2017). Mental health in the workplace:Towards evidence-based practice. Canadian Psychology / Psychologie Canadienne, 58(1), 1-6. doi:10.1037/cap0000084

Kidger, J., Brockman, R., Tilling, K., Campbell, R., Ford, T., Araya, R., . . Gunnell, D. (2016). Teachers' wellbeing and depressive symptoms, and associated risk factors: A large cross sectional study in English secondary schools. Journal of Affective Disorders, 192, 76-82. doi:10.1016/j.jad.2015.11.054

Koles, B., O'Connor, E. E. og Collins, B.A. (2013). Associations between child and teacher characteristics and quality of teacher-child relationships: The case of Hungary. European Early Childhood Education Research Journal, 21(1), 53-76. doi:10.1080/1350293X.2012.760337

Laufey Axelsdóttir og Gyða Margrét Pétursdóttir. (2014). Staða leikskólakennara í tveimur sveitarfélögum í kjölfar hruns. Stjórnmál og stjórnsýsla, 1(10), 77-98. doi:10.13177/irpa.a.2014.10.1.5

Liu, B., Yang, K. og Yu, W. (2014). Work-related stressors and health-related outcomes in public service: Examining the role of public service motivation. The American Review of Public Administration, 45(6), 653-673. doi:10.1177/0275074014524298

Manlove, E. E. (1993). Multiple correlates of burnout in child care workers. Early Childhood Research Quarterly, 8(4), 499-518. doi:10.1016/s0885-2006(05)80082-1

Martin, A., Karanika-Murray, M., Biron, C. og Sanderson, K. (2016). The psychosocial work environment, employee mental health and organizational interventions: Improving research and practice by taking a multilevel approach. Stress and Health, 32(3), 201-215. doi:10.1002/smi.2593

Mashburn, A. J., Pianta, R. C., Hamre, B. K., Downer, J. T., Barbarin, O. A., Bryant, D., . . Howes, C. (2008). Measures of classroom quality in prekindergarten and children's development of academic, language, and social skills. Child Development, 79(3), 732-749. doi:10.1111/j.1467-8624.2008.01154.x

McGinty, A. S., Justice, L. og Rimm-Kaufman, S. E. (2008). Sense of school community for preschool teachers serving at-risk children. Early Education \& Development, 19(2), 361-384. doi:10.1080/10409280801964036

Mellor, N. og Webster, J. (2013). Enablers and challenges in implementing a comprehensive workplace health and well-being approach. International Journal of Workplace Health Management, 6(2), 129-142. doi:10.1108/ IJWHM-08-2011-0018

Mennta- og menningarmálaráđuneytið. (2013). Aðalnámskrá leikskóla 2011. Reykjavík: Höfundur.

Rentzou, K. (2012). Examination of work environment factors relating to burnout syndrome of early childhood educators in Greece. Child Care in Practice, 18(2), 165-181. doi:10.1080/13575279.2012.657609

Riggio, R. E. (2009). Introduction to industrial/organizational psychology (5. útgáfa). Upper Saddle River, NJ: Pearson Prentice Hall.

Rimm-Kaufman, S. E. og Hamre, B. K. (2010). The role of psychological and developmental science in efforts to improve teacher quality. Teachers College Record, 112(12), 2988-3023.

Schulte, P. og Vainio, H. (2010). Well-being at work - overview and perspective. Scandinavian Journal of Work, Environment \& Health, 36(5), 422-429. doi:10.5271/sjweh.3076

Sigursteinsdóttir, H. og Rafnsdóttir, G. L. (2015). Sickness and sickness absence of remaining employees in a time of economic crisis. A study among employees of municipalities in Iceland. Social Science and Medicine, 132, 95-102. Sótt af http://www.sciencedirect.com/science/article/pii/S0277953615001677

Stansfeld, S. og Candy, B. (2006). Psychosocial work environment and mental health-A meta-analytic review. Scandinavian Journal of Work, Environment \& Health, 32(6), 443-462. doi:10.5271/sjweh.1050 
Stauffer, S. D. og Mason, E. C. M. (2013). Addressing elementary school teachers' professional stressors: Practical suggestions for schools and administrators. Educational Administration Quarterly, 49(5), 809-837. doi:10.1177/0013161X13482578

Travers, C. J. og Cooper, C. L. (1996). Teachers under pressure: Stress in the teaching profession. London og New York: Routledge.

Valgerður Magnúsdóttir og Anna Dóra Magnúsdóttir. (2008). Faglegt sjálfstraust grunnskólakennara. Uppeldi og menntun, 17(1), 69-86.

Wells, M. B. (2015). Predicting preschool teacher retention and turnover in newly hired Head Start teachers across the first half of the school year. Early Childhood Research Quarterly, 30, 152-159. doi:10.1016/j. ecresq.2014.10.003

Whitaker, R. C., Dearth-Wesley,T. og Gooze, R.A. (2015). Workplace stress and the quality of teacher-children relationships in Head Start. Early Childhood Research Quarterly, 30, 57-69. doi:10.1016/j.ecresq.2014.08.008

Dórdís Pórðardóttir. (2005). Konur og kennsla. Í Arna H. Jónsdóttir, Steinunn H. Lárusdóttir og Dórdís Dórðardóttir (ritstjórar), Kynjamyndir í skólastarfi (bls. 67-84). Reykjavík: Rannsóknarstofnun Kennaraháskóla Íslands.

Guðbjörg Linda Rafnsdóttir og Hjördís Sigursteinsdóttir (2019).

Líðan leikskólakennara og leiðbeinenda í leikskólum í kjölfar efnahagshrunsins.

Netla - Veftímarit um uppeldi og menntun. Menntavísindasvið Háskóla Íslands.

Sótt af http://netla.hi.is/serrit/2019/menntun_barna_leik_grunn/06.pdf

DOI: https://doi.org/10.24270/serritnetla.2019.38 